\title{
Search for alternate hosts of the coconut Cape Saint Paul Wilt Disease pathogen
}

Egya Ndede YANKEY ${ }^{1}$

Fabian PILET ${ }^{2}$

Robert Nketsia QUAICOE ${ }^{1}$

Sylvester Kuuna DERY ${ }^{1}$

Michel DOLLET ${ }^{2}$

Victoria Pearl DZOGBEFIA ${ }^{3}$

${ }^{1}$ CSIR-OPRI, coconut Research Programme,

Box 245 Sekondi, Ghana

<ndedeyankey@yahoo.com>

${ }^{2}$ CIRAD, Research Unit 29, Etiology/Wilts,

Dept. Biological systems

${ }^{3}$ KNUST, Faculty of Biosciences, Kumasi, Ghana

The coconut palm (Cocos nucifera L.) is considered the most important crop along the coastal belt of West Africa and can be grown (with minimal capital outlay) in poor sandy salt-loaded soils where very few or no other crop would survive $[1,2]$. It is reported that about $4.2 \%$ of Ghana's population depend on coconut for their livelihood [3]. The cultivation, processing and marketing of the crop supports the livelihoods of many poor coastal people and help sustain the environment [4]. In 1932, a disease called Lethal Yellowing (LY) was detected among some palms in the Volta Region of Ghana and ever since the fortunes of the coconut industry has been on the decline.

$\mathrm{LY}$ is a highly destructive and fast spreading disease affecting coconut palm and at least 35 other palm species in the Americas [5]. The disease has brought great distress to several rural coastal communities engaged in the coconut industry in Ghana, leaving them without a sustainable source of livelihood [6]. The destruction of the coconut palms has environmental repercussions too as previously covered lands become exposed leaving these areas prone to degradation.

LY diseases are caused by phytoplasmas, which are essentially cell wall-less prokaryotes belonging to the class Mollicutes. Plant-to-plant transmission of these pathogens are carried out by insect vectors (plant hoppers and leaf hoppers), through vegetative propagation of infected plant materials or by graft inoculation [7]. Phytoplasmas cannot be cultured in vitro,

\begin{abstract}
Lethal Yellowing disease locally called Cape Saint Paul wilt disease (CSPWD) is the bane of the coconut industry in Chana and is caused by a phytoplasma. In Ghana, there are areas where the disease has re-infected re-plantings long after decimating all the palms in the area. This brings to the fore the possibility of alternate hosts in the spread of the disease because the pathogen is an obligate parasite. In this work, a number of plants were screened for their host status to the CSPWD pathogen. The presence of phytoplasmas in these plants was tested by polymerase chain reaction analysis using universal phytoplasma primers P1/P7 and CSPWD-specific primers G813/GAKSR. Although Desmodium adscendens tested positive to the CSPWD-specific primers, cloning and sequencing did not confirm it as an alternate host. The identification of alternate hosts will help us to evolve sound control strategies against the spread of the disease.
\end{abstract}

Key words: Chana, coconut, phytoplasmas, alternate hosts

a phenomenon due probably to the lack of essential genes and functions [8].

After the occurrence of LY diseases in 1964 at Cape Three Points in the Western Region (WR) of Ghana, in 1977, the Crops Research Institute of the Council for Scientific and Industrial Research (CSIR-CRI) planted in some varieties

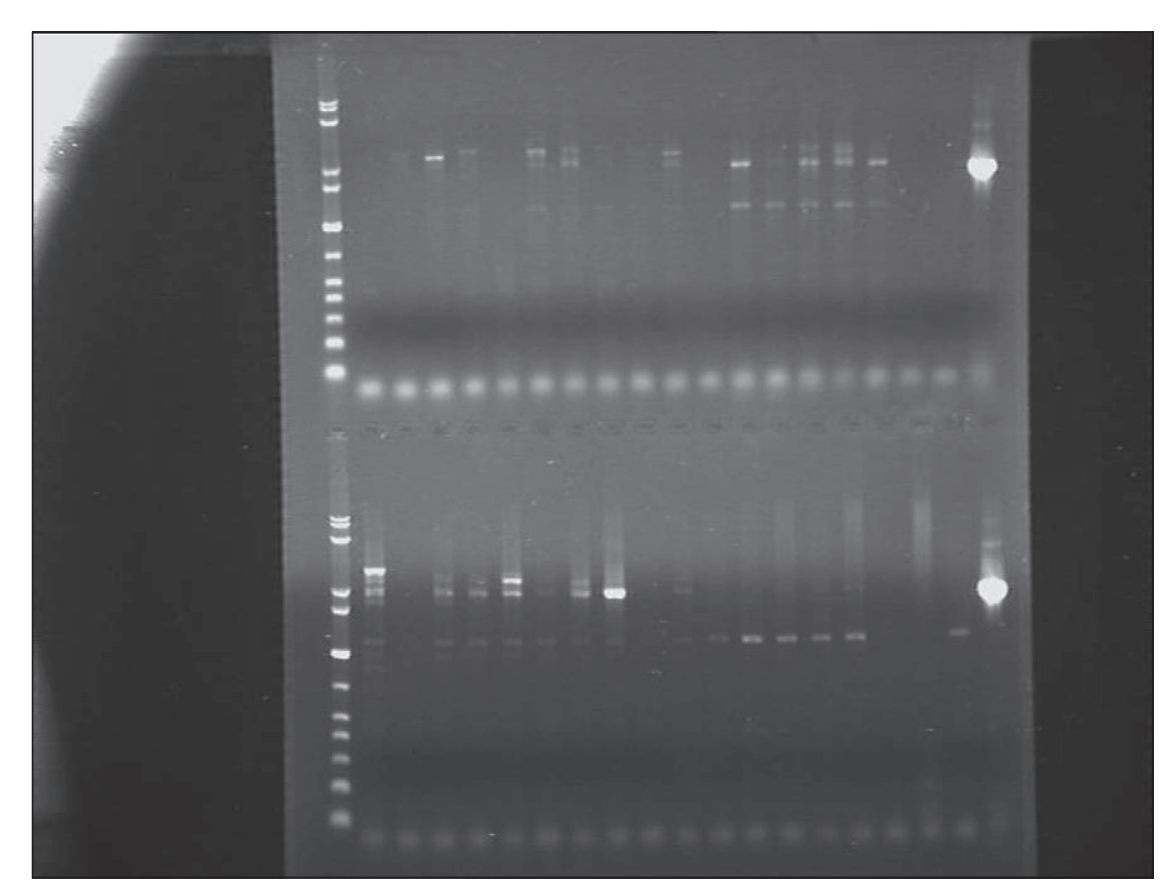

Figure 1. Amplification of samples with primers P1/P7. to evaluate their resistance to the disease. All the varieties succumbed to the disease [6]. Then in 1981, the Ministry of Agriculture under the France-Ghana-Cote d'Ivoire Coconut Project brought in some varieties from outside the country to screen for their resistance to the disease. The disease decimated these palms as 
well with the exception of the Sri Lanka Green Dwarf (SCD) variety [6]. In 1995, the CSIR - Oil Palm Research Institute, Coconut Research Programme under the European Commission of Science and Technology for Development III Project also imported some varieties from Cote d'Ivoire for resistance trials. Yet again, the disease has cleared almost all the palms $(62.3 \%)$ [9]. It is in the light of this history that the possibility of the presence of alternate hosts of the Cape Saint Paul Wilt Disease (CSPWD) phytoplasma was investigated. The hypothesis being that the phytoplasma, an obligate parasite, needed another host to survive during the periods when their primary hosts, the coconuts, were unavailable due to death from the disease. In the Americas, LY phytoplasma is known to have other hosts other than the coconut. This situation may hold true for other areas affected by similar LY-type coconut diseases, such as CSPWD.

In choosing the species to sample, priority was given to plants related to known hosts of the coconut LY phytoplasma. Emilia fosbergii and Synedrella nodiflora are reported to be alternate hosts in Jamaica [10], so Emelia sonchifolia and S. nodiflora were sampled. Plants that have been reported to host any type of phytoplasma were also sampled. As a result, pepper, tomato, potato, cassava, sugar cane, Solanum spp. and Euphorbia spp., which are reported to host phytoplasmas [11-14] were sampled. Plants showing any of the general symptoms of phytoplasma infection such as stunting, yellowing, withering, witches' broom (proliferating shoots) [15] as well as some asymptomatic plants were also selected.

\section{Materials and methods}

\section{Sampling sites}

Sampling of plant species was carried out from two locations: Cape Three Points in the WR and Asebu in the Central Region (CR). Cape Three Points is approximately $66 \mathrm{~km}$ southwest from Sekondi. Asebu is approximately $100 \mathrm{~km}$ northeast from Sekondi; both are active disease foci.

\section{Sampling period}

Sampling was done twice in a year: one in the rainy season and the other in the dry season. This was done to take account of the effect of changes in environmental conditions on the dynamics of plants and insect life. For example, some plants that cannot withstand drought die out during the dry season and this may be true for the insect vector population fluctuation as well. The implication is that some potential hosts of the pathogen can be missed if sam- pling is not done in the two seasons. The rainy season sampling took place from July to December 2007 and that of the dry season was done from March to April 2008.

\section{Sampling methodology}

The sampled species were mainly grasses, a few shrubs and a few tree plants. Fifteen species

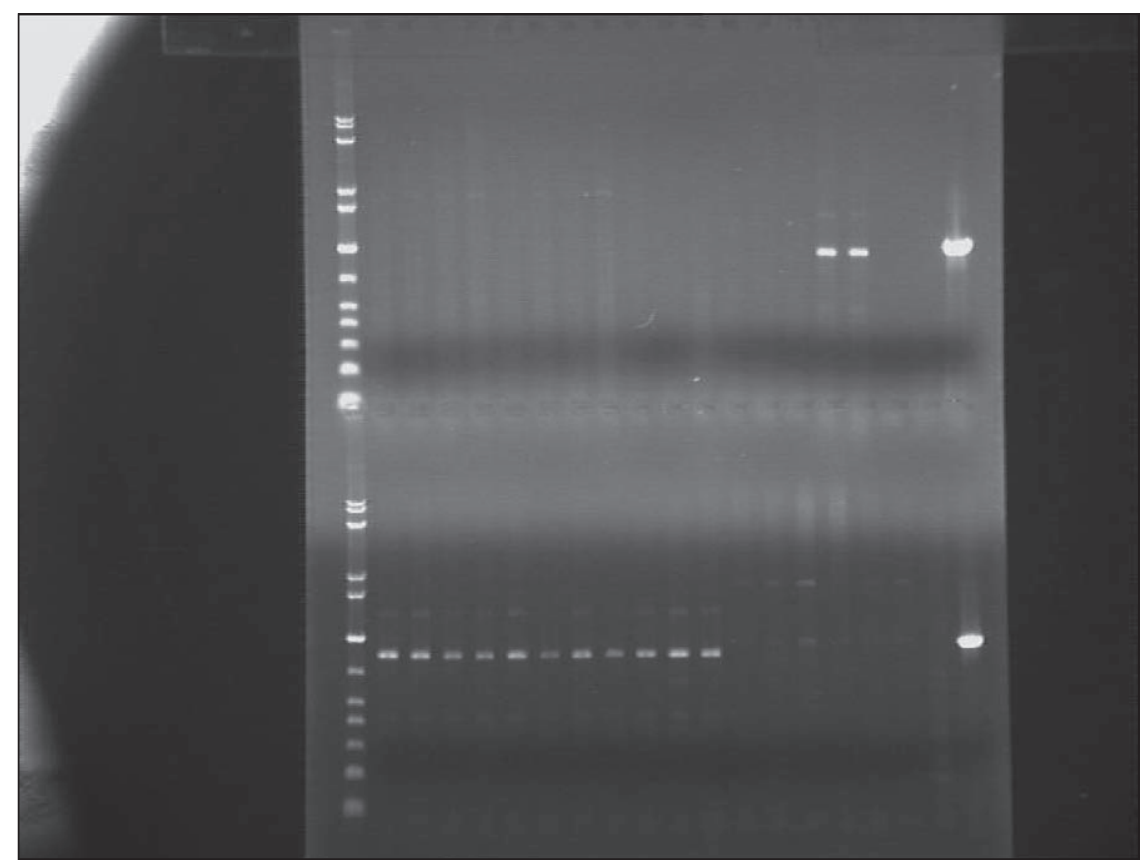

Figure 2. Amplification of Desmodium adscendens samples with G813/GAKSR.

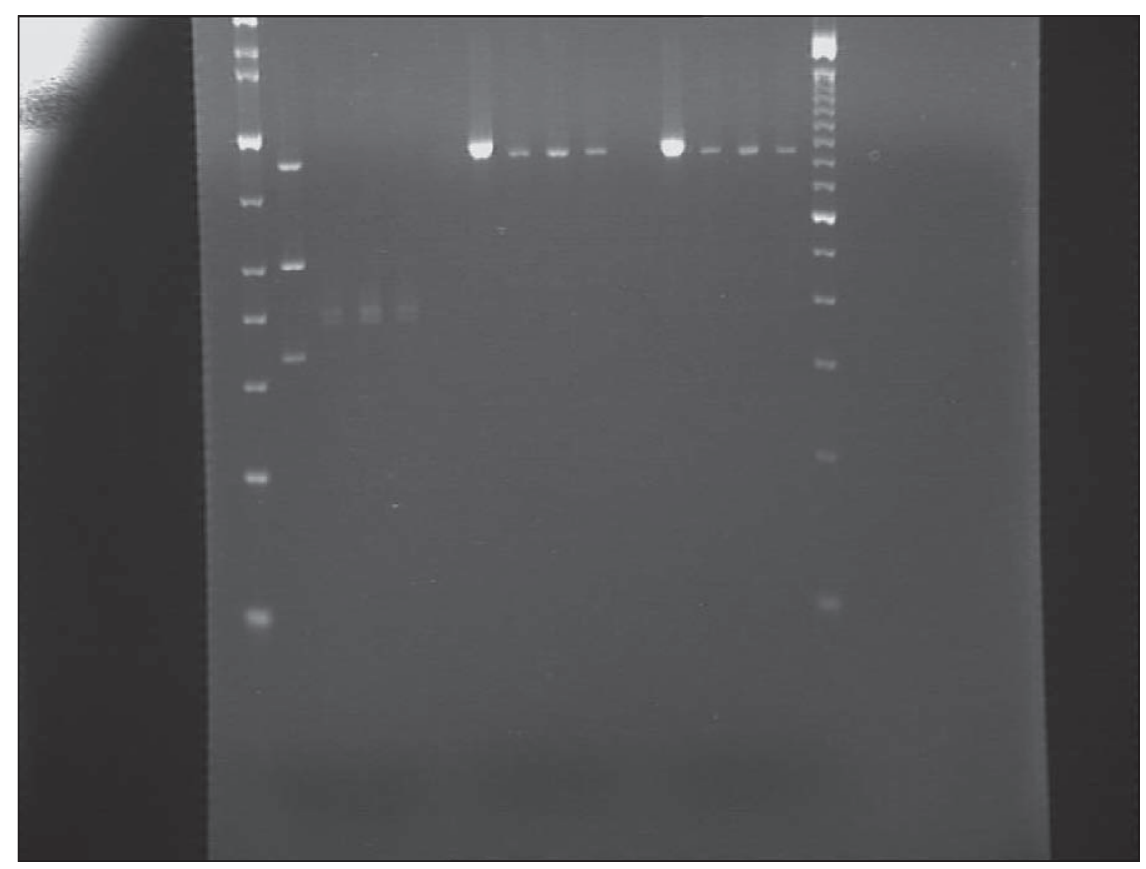

Figure 3. Restriction fragment length polymorphism (RFLP) analysis of three samples of Desmodium adscendens (G813/GAKSR products) using three restriction endonucleases. 


\section{Total DNA extraction from plant tissue}

For each species, two individual plants were pooled together to give one sample. Hence, 15 DNA samples were prepared for each species. One gram of each sample was ground in 5-mL Cetyl trimethyl ammonium bromide (CTAB) and the DNA extracted according to the protocol of Daire et al., 1997 [16].

\section{Polymerase chain reaction and gel electrophoresis}

The DNA samples were assayed for the presence of phytoplasmas using phytoplasma universal primer pair P1 (5'-AAG AGT TTG ATC CTG GCT CAG GAT T-3') [17] and P7 (5'-CGT CCT TCA TCG GCT CTT-3') [18]. Positives from this test were screened for the CSPWD phytoplasma using primers G813f (5'-CTA AGT GTC GGG
GGT TTC C-3') and GAKSR (5'-TTG AAT AAG AGG AAT GTG G-3') [19]. The polymerase chain reaction (PCR) was performed using a PTC-100 Programmable Thermal Controller manufactured by MJ Research Inc (Waltham, Massachusett, USA). The PCR products were analysed and visualised by gel electrophoresis on a 0.8\% agarose gel prepared using Tris-BorateEthylenediaminetetraacetic acid (EDTA) buffer (TBE) (1x) and stained with ethidium bromide. A 1-kb ladder (Invitrogen/Quiagen) was loaded in either the first or last lane. The gel was visualised and photographed under UV light. Negative controls consisted of reaction mixtures with DNA template from healthy coconut palms. DNA templates from CSPWD-infected palms were used for the positive controls and the blanks had the DNA templates substituted with water.

Table 1. Results of assay of rainy season samples.

\begin{tabular}{|c|c|c|c|c|c|c|}
\hline & \multicolumn{6}{|l|}{ Primers } \\
\hline & \multicolumn{3}{|l|}{ P1/P7 } & \multicolumn{3}{|c|}{ G813/GAKSR } \\
\hline & $\begin{array}{l}\text { No. of } \\
\text { samples }\end{array}$ & $\begin{array}{l}\text { No. of } \\
\text { positives }\end{array}$ & $\%+$ & $\begin{array}{l}\text { No. of } \\
\text { samples }\end{array}$ & $\begin{array}{l}\text { No. of } \\
\text { positives }\end{array}$ & $\%+v e$ \\
\hline \multicolumn{7}{|l|}{ Plant species (Asebu) } \\
\hline Commelina benghalensis & 15 & 7 & 46.7 & 7 & 0 & 0 \\
\hline Solanum torvum & 15 & 0 & 0 & 0 & 0 & 0 \\
\hline Calapogonium mucunoides & 15 & 2 & 13.3 & 2 & 0 & 0 \\
\hline Desmodium adscendeus & 15 & 13 & 86.7 & 13 & 13 & 100 \\
\hline Malacantha alnifolia & 15 & 4 & 26.7 & 4 & 0 & 0 \\
\hline Panicum maximum & 15 & 1 & 6.7 & 1 & 0 & 0 \\
\hline Citrus limon & 15 & 3 & 20 & 3 & 0 & 0 \\
\hline Nephrolepis biserrata & 15 & 0 & 0 & 0 & 0 & 0 \\
\hline Sida acuta & 15 & 0 & 0 & 0 & 0 & 0 \\
\hline Tridax procumbens & 15 & 0 & 0 & 0 & 0 & 0 \\
\hline Pennisetum purpureum & 15 & 0 & 0 & 0 & 0 & 0 \\
\hline Ficus exasperata & 15 & 0 & 0 & 0 & 0 & 0 \\
\hline Oxytenanthera abyssinica & 15 & 0 & 0 & 0 & 0 & 0 \\
\hline Chromolaena odorata & 15 & 0 & 0 & 0 & 0 & 0 \\
\hline Rauvolfia vomitoria & 15 & 0 & 0 & 0 & 0 & 0 \\
\hline \multicolumn{7}{|l|}{$\begin{array}{l}\text { Plant species } \\
\text { (Cape Three Points) }\end{array}$} \\
\hline Setaria megaphylla & 15 & 0 & 0 & 0 & 0 & 0 \\
\hline Mimosa pudica & 15 & 0 & 0 & 0 & 0 & 0 \\
\hline Stachytarpheta indica & 15 & 0 & 0 & 0 & 0 & 0 \\
\hline Aspilia africana & 15 & 0 & 0 & 0 & 0 & 0 \\
\hline Borreria scabra & 15 & 0 & 0 & 0 & 0 & 0 \\
\hline Saccharum officinale & 15 & 0 & 0 & 0 & 0 & 0 \\
\hline Dissotis rotundifolia & 15 & 0 & 0 & 0 & 0 & 0 \\
\hline Asystasia gangetica & 15 & 0 & 0 & 0 & 0 & 0 \\
\hline Ananas sativa & 15 & 0 & 0 & 0 & 0 & 0 \\
\hline Rauvolfia vomitoria & 15 & 0 & 0 & 0 & 0 & 0 \\
\hline Flagellaria guineensis & 15 & 0 & 0 & 0 & 0 & 0 \\
\hline Pueraria phaseoloides & 15 & 0 & 0 & 0 & 0 & 0 \\
\hline Manihot esculenta & 15 & 0 & 0 & 0 & 0 & 0 \\
\hline Voacanga africana & 15 & 0 & 0 & 0 & 0 & 0 \\
\hline
\end{tabular}

Restriction fragment length polymorphism (RFLP)

Samples that tested positive to the CSPWDspecific primers were digested with restriction endonucleases. The enzymes used were RSA1, EcoR1, HindIII and Alu1. The reaction was incubated in a water bath at $37^{\circ} \mathrm{C}$ for $9 \mathrm{~h}$. Analysis of digestion product was done by electrophoresis on a $2 \%$ agarose gel.

\section{Results}

Samples from plants such as Calapogon mucunoides (Calapo) and Desmodium adscendens were amplified at the expected size of $1.8 \mathrm{~kb}$ when primers P1/P7 were applied (figure 1). When the specific primers G813/GAKSR were applied to the positive samples from the P1/P7 test, only the $D$. adscendeus samples were amplified at the expected size of $0.9 \mathrm{~kb}$ (figure 2); when restriction digestion was carried out on G813/GAKSR PCR products of D. adscendeus samples, RSA 1 did not produce the expected fragment sizes of 498, 311 and $21 \mathrm{~kb}$; however, Hind III and EcoR1 produced fragments corresponding to the profile of the CSPWD phytoplasma of the expected size $855 \mathrm{~kb}$ (figure 3). Results of the PCR assay of all the samples are presented in tables 1 and 2 .

\section{Cloning and sequencing}

A sample of $D$. adscendeus was cloned and sequenced by Cogenics society (France). DNA sequences from the sample were determined to be related to Bacillus megaterium and Rhodobacter sphaeroides.

\section{Discussion}

The results so far have failed to identify any alternate hosts of the CSPWD phytoplasma. However, we cannot conclude that there are no alternate hosts in the two areas because only a few plants were screened from the hundreds of plant species that can be found at the two places. Although plants like cassava, sugar cane, Solanum spp. and Stachytarphta spp. have been reported to host at least a type of phytoplasma elsewhere, this was not the case in this work as no amplifications were obtained from their samples when screened with the phytoplasma universal primer pair P1/P7. This could mean that the phytoplasmas infecting these species are not in the environment of the two sampling sites. The results of this work underscore the need to clone and sequence before making conclusions. This work also demonstrates the need to search for more reliable specific primers for detecting the CSPWD phytoplasma. As far as we are concerned, this work is the first major attempt at finding alternate hosts of the 
Table 2. Results of assay of dry season samples.

\begin{tabular}{|c|c|c|c|c|c|c|}
\hline & \multicolumn{6}{|l|}{ Primers } \\
\hline & \multicolumn{3}{|l|}{ P1/P7 } & \multicolumn{3}{|c|}{ G813/GAKSR } \\
\hline & $\begin{array}{l}\text { No. of } \\
\text { samples }\end{array}$ & $\begin{array}{l}\text { No. of } \\
\text { positives }\end{array}$ & $\%+$ & $\begin{array}{l}\text { No. of } \\
\text { samples }\end{array}$ & $\begin{array}{l}\text { No. of } \\
\text { positives }\end{array}$ & $\%+v e$ \\
\hline \multicolumn{7}{|l|}{ Plant species (Asebu) } \\
\hline Stachytarpheta indica & 15 & 0 & 0 & 0 & 0 & 0 \\
\hline Desmodium adscendeus & 15 & 0 & 0 & 0 & 0 & 0 \\
\hline Synedrella nodiflora & 10 & 0 & 0 & 0 & 0 & 0 \\
\hline Ipomoea involucrata & 15 & 0 & 0 & 0 & 0 & 0 \\
\hline Lycopersicon esculentum & 4 & 0 & 0 & 0 & 0 & 0 \\
\hline Jussiae spp. & 15 & 0 & 0 & 0 & 0 & 0 \\
\hline Sporobolus pyramidalis & 15 & 0 & 0 & 0 & 0 & 0 \\
\hline Bracharia deflexa & 15 & 0 & 0 & 0 & 0 & 0 \\
\hline Cymbopogon citrates & 15 & 0 & 0 & 0 & 0 & 0 \\
\hline Capsicum annuum & 15 & 0 & 0 & 0 & 0 & 0 \\
\hline Emilia sonchifolia & 15 & 0 & 0 & 0 & 0 & 0 \\
\hline Eleusine indica & 15 & 0 & 0 & 0 & 0 & 0 \\
\hline Digitaria adscendens & 15 & 0 & 0 & 0 & 0 & 0 \\
\hline Euphorbia heterophylla & 15 & 0 & 0 & 0 & 0 & 0 \\
\hline Solanum tuberosum & 15 & 0 & 0 & 0 & 0 & 0 \\
\hline \multicolumn{7}{|l|}{$\begin{array}{l}\text { Plant species } \\
\text { (Cape Three Points) }\end{array}$} \\
\hline Paspalum scrobiculatum & 15 & 0 & 0 & 0 & 0 & 0 \\
\hline Panicum laxum & 15 & 0 & 0 & 0 & 0 & 0 \\
\hline Cassytha filiformis & 15 & 0 & 0 & 0 & 0 & 0 \\
\hline Lantana camara & 15 & 0 & 0 & 0 & 0 & 0 \\
\hline Clerodendrom capitatum & 15 & 0 & 0 & 0 & 0 & 0 \\
\hline Morinda lucida & 15 & 0 & 0 & 0 & 0 & 0 \\
\hline Chassalia kolly & 15 & 0 & 0 & 0 & 0 & 0 \\
\hline Rottboellia exaltata & 15 & 0 & 0 & 0 & 0 & 0 \\
\hline Cyperus spp. & 15 & 0 & 0 & 0 & 0 & 0 \\
\hline Alchornea cordifolia & 15 & 0 & 0 & 0 & 0 & 0 \\
\hline Sanseviera liberica & 15 & 4 & 26.7 & 0 & 0 & 0 \\
\hline Pennisetum pedicellatum & 15 & 0 & 0 & 0 & 0 & 0 \\
\hline Spigelia anthelmia & 15 & 0 & 0 & 0 & 0 & 0 \\
\hline Phyllanthus amarus & 15 & 0 & 0 & 0 & 0 & 0 \\
\hline Justica flava & 15 & 0 & 0 & 0 & 0 & 0 \\
\hline
\end{tabular}

CSPWD phytoplasma and the search needs to continue with more species being screened.

Acknowledgement. The authors are grateful to the Government of France for funding this work, which was part of the full sponsorship Egya Ndede Yankey received to study for his master's degree.

\section{REFERENCES}

1. Ofori F, Nkansah-Poku J. Cape Saint Paul Wilt Disease of coconut in Ghana: History of its occurrence and spread. In: Eden-Green SJ, Ofori F, eds. Proceedings of an International workshop on Lethal Yellowing-like Diseases of coconut. Elimina, Chana, November 1995: 27-32.

2. Bourdeix R, Konan IL, N'cho YP. Coconut, a guide to traditional and improved varieties. Editions Diversiflora, 2005.
6. Dery SK, N'Cho YP, Sangare A, Arkhurst ED. Cape St. Paul Wilt Disease of coconut in Ghana. In: Eden-Green SJ, Ofori F, eds. Proceedings of an International workshop on Lethal Yellowing-like Diseases of coconut. Elimina, Ghana, November 1995.

7. Kirkpatrick BC. Mycoplasma-like organisms plant and invertebrate pathogens. In: Balows A, Truper HG, Dworkin M, Harder W, Schleifer $\mathrm{KH}$, eds. The prokaryotes, 2nd edn, vol. 4. 1992: 4050-67.

8. Razin S. Molecular biology and genomics of Mollicutes. Bull Insectol 2007; 60: 101-3.

9. OPRI Annual Reports. Report of the Pathology Division, Coconut Research Programme. Annual Report. Oil Palm Research Institute (OPRI), Council for Scientific and Industrial Research (CSIR), Ghana, 2006.

10. Brown SE, Been BO, McLaughlini WA. First report of the presence of the lethal yellowing group (16r IV) of phytoplasma in the weeds Emelia fosbergii and Synedrella nodiflora in Jamaica. British society for plant pathology, 2007.

11. Montano HG, Brioso PST, Pimental JP. List of phytoplasma hosts in Brazil. Bull Insectol 2007; 60: $129-30$.

12. Gungoosingh-Bunwaree A, Bertaccini A, Benimadhu SP. Presence of phytoplasma infections in tomato plants in Mauritius. Bull Insectol 2007; 60: 151-2.

13. Nasir MM, Mughal SM, Khan SM. Occurrence, distribution and detection of potato purple top phytoplasma disease in the Punjab (Pakistan). Bull Insectol 2007; 60: 337-8.

14. Lebsky V, Poghosyan A. Phytoplasma associated diseases in tomato and pepper in the state of BCS, Mexico: a brief overview. Bull Insectol 2007; 60: 131-2.

15. Lee IM, Davies R, Gundersen-Rindal DE. Phytoplasma: phytopathogenic mollicutes. Annual Rev Microbiol 2000; 54: 221-55.

16. Daire X, Claire D, Reinert W, Boudon E. Detection and differentiation of grapevine yellows phytoplasmas belonging to the elm yellows group and to the stolbur subgroup by PCR amplification of non-ribosomal DNA. Eur J Plant Pathol 1997; 103: 507-14.

17. Deng S, Hiruki C. Amplification of 16 SrRNA genes from culturable and nonculturable molicutes. J Microbiol Met 1991; 14: 53-61.

18. Smart C, Schneider B, Blomquist CL, Guerra LJ, Harrison NA, Ahrens U, Lorenz KH, Seemuller E, Kirkpatrick BC. Phytoplasma - specific PCR primers based on sequences of the 16-23S rRNA spacer region. Appl Environ Microbiol 1996; 62: 2988-93.

5. Harrison NA, Cordova I, Richardson P, Dibonto $R$. Detection and diagnosis of lethal yellowing. In: Oroeza C, Verdeil JL, Ashburner GR, Cardena $\mathrm{R}$, Santamaria JM, eds. Current advances in coconut biotechnology. 1999: 183-96. 